\section{Käytännöllinen opas vuorovaikutukseen}

Ståhlberg, Leena (2019). Pienryhmäohjaajan opas. PS-kustannus. 169 sivua.

NIMENSÄ MUKAISEsti Pienryhmäohjaajan opas on käytännön opas ohjaustyötä tekevälle. Ohjaustyö tulee nähdä pedagogisena jatkumona, jonka juoni muotoutuu tavoitteenasettelun ja suunnittelun kautta kohti aitoa kohtaamista ja oppijalähtöistä jatkuvan oppimisen prosessia. Ohjauksessa ja opetustyössä on useita tasoja, joista toinen äärilaita edustaa yksilöohjausta ja toinen suurryhmäopetusta. Väliin jää kuitenkin lukemattomia pienryhmäohjauksen tasoja erilaisine asiakasryhmineen. Juuri heidän parissaan työskenteleville teoksessa on konkreettisia menetelmiä ja työkaluja.

\section{ENSIN TEORIA, SITTEN \\ MENETELMÄT}

Opas on teemoitettu kahteen osaan: Ensimmäinen osa käsittelee pienryhmäohjausta kirjoittajan omien kokemusten ja teorian kautta. Toinen osa keskittyy pienryhmäohjauksen erilaisiin menetelmiin.

Oppaassa korostetaan ohjaajan roolia: "Pienryhmäohjaajan keskeinen tehtävä on kannustaen nostaa esille sekä ryhmätoiminnassa että yksittäisen ryhmän jäsenen toiminnassa ilmenevät vahvuudet ja potentiaalit”. Ensimmäisessä osassa tarkastellaan pienryhmäohjaajan ominaisuuksia ja kohtaamisen taitoja: "KOH-
TAA - Kuuntele, Ole oma itsesi, Huomioi, Tue ja kannusta, Asetu toisen asemaan ja Arvosta."

Kirjoittaja kuvaa pienryhmätoiminnan prosessin ennakkosuunnittelusta alun orientointiin ja eri työskentelyvaiheisiin. On hyvä, että ohjaustoimintaa tarkastellaan monipuolisesti tilaratkaisut, aikataulut, ryhmän koko ja sen dynamiikka huomioon ottaen. Kirjoittaja pohtii lisäksi pariohjauksen tarjoamia mahdollisuuksia ja käytännön hyötyjä.

Oppaan toinen osa sisältää monipuolisen valmennuksellisen menetelmäpaketin. Kirjoittaja tarjoaa ohjaajalle itselleen hyödyllisiä reflektoinnin työkaluja. Harjoitukset on tarkoitettu toteutettavaksi pienryhmäohjauksen eri vaiheissa. Kirjoittaja kannustaa lukijaa kokeilemaan ja soveltamaan niitä oman ryhmänsä tavoitteiden mukaisesti. Pienryhmävalmennus kuvataan vaiheittain, ja monipuoliset liitteet auttavat lukijaa suunnittelemaan ja toteuttamaan omaa ohjaustoimintaa.

\section{PERUSTANA KIRJOITTAJAN OMAT KOKEMUKSET}

Leena Ståhlbergillä on monipuolinen kokemus pienryhmien ohjauksesta, kuten opinto-ohjauksessa, oppilaanohjauksessa sekä työhönja uravalmennuksessa. Suurin osa

\section{Leena Ståhlberg \\ PIENRYHMÄ- OHJAAJAN opis}

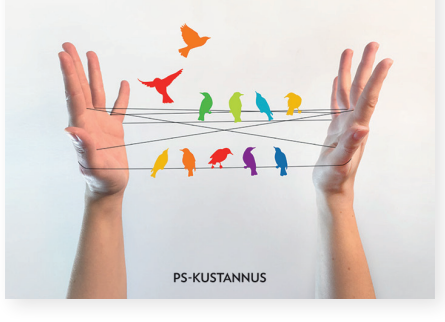

oppaan neuvoista, ohjeista ja kokemuksista ei perustu tutkimustietoon vaan perustuu kirjoittajan omiin kokemuksiin ryhmäohjauksista, mikä on samalla sekä teoksen vahvuus että heikkous.

Lukija hyötyy monipuolisista menetelmistä, mutta toivoisin vielä kriittisempää arviointia omiin kokemuksiin nojanneista ryhmäohjauksista. Usein epäonnistumiset ryhmätoiminnassa ja niiden sanoittaminen lukijalle tekevät tilaa arvokkaille oppimiskokemuksille. Asiakkaidenkin ääni olisi ollut syytä tuoda esiin vielä vahvemmin.

Käytännöllinen opas on hyödyksi erityisesti pienryhmäohjausta omassa työssään toteuttaville ohjaajille, valmentajille, opettajille ja muille ohjausta tekeville eri alojen ammattilaisille. Ennen kaikkea siitä hyötyvät ne, jotka haluavat kehittää aitoa kohtaamista, vuorovaikutusosaamista ja dialogia omassa asiakastyössään.

\section{JANI SIIRILÄ}

FT, yliopettaja

Haaga-Helia - Ammatillinen

opettajakorkeakoulu 